\title{
ATTACHMENT OF THE BODY UPON CIVIL PROCESS.
}

A member of the Hartford County Bar is to be tried by the court next week, at the information of the Grievance Committee of the Bar, upon several charges; the principal one accuses him of using, in a wholesale way, writs with counts in fraud to aid him in collecting debts for his clients. One of these clients conducted a collection business under another than his baptismal name. The offense is a peculiarly mean and cowardly one. Were a lawyer to threaten personal violence to his client's debtor as an alternative to immediate payment of the debt the debtor could at least defend himself, and the result of a scrimmage might find the persecutor at the bottom of the pile. But incarceration by the command of a sovereign State is quite another thing, and one where resistance affords no chance for victory. The method charged upon this man is that he instituted such writs by the hundred in trying to collect debts; if a defendant appeared he withdrew the suit or struck out the counts in fraud and took judgment upon the counts in contract. In most cases the debtor, who did not understand the perils of an action in tort, paid no attention to the suit and let judgment go against him by default. Then, armed with an execution which ran against the body the lawyer proceeded to make it quite unpleasant for the defendant, and of course in many cases extorted money from parties, who thought commitment to jail inconvenient and undesirable. This practice, whether or not carried on by this man, who denies it, is sard to be not infrequently used by miscreants who get into the profession. Can we purge the community of such offenses by occasionally hunting down a shining example of wickedness and disbarring him? We think a more comprehensive remedy should be sought. Some years ago the New Haven bar, either as a body or by leading representatives, proposed, at a State bar meeting, that attachments of property upon mesne process should be with some exceptions, abolished. This would have been a return to common law practice. The measure on the whole was deemed to be too radical and too destructive of long-continued usage, whose results are woven into our habits and jurisprudence. 
In Connecticut an attachment of property upon mesne process is obtained very easily. The State allows the signature of writs which command attachments by many officials, including justices of the peace and commissioners of the Superior Court. As these offices are practically open to all members of the bar, the statutes therefore permit all lawyers to issue writs with directions to attach property in favor of their clients. This right is some times abused, and the New Haven lawyers before alluded to cited instances of gross abuse. But excessive attachments of property are easily cut down and all such attachments are dissoluble upon substitution of a bond. But the attachment of a debtor's body, although equally easy to obtain, leads to quite different results and larger annoyances.

At common law a capias was issued after proof that the judgment was unsatisfied, and the poor defendant was taken to prison where there was a moral certainty that he could not satisfy the judgment, as the law by the very fact of his incarceration, took away his earning capacity. The English prisons in earlier days were full of poor fellows, held in their vile chambers, not for punishment-for nearly all criminals were disposed of by the death penalty - but for detention. Modern civilization abolished imprisonment for debt. Connecticut fell into this good line in 1842. But an attachment of a defendant's body upon mesne and final process is still open in suits for torts. Meantime the criminal law has been enlarged to protect society more fully than formerly, against swindlers and breakers. of trust.

The process of attaching the body in civil process is seldom used for a morally legitimate purpose, if there is any such purpose, because the provisions of the statutes relative to freedom of jail limits and the poor debtor's oath, and for getting possession of a defendant's property by disclosure and other proceedings in insolvency, make its use unprofitable to the suitor. The plaintiff incurs all the initial expenses of the process, and usually discovers in the end that he has only sent more good money in an ineffectual effort to collect a bad claim.

Recurring to our original question, how can the abuse of this power by scoundrelly lawyers-and we should be thankful that the profession is so seldom dishonored by them-be prevented? These plans suggest themselves:

First. Require of the plaintiff that he furnish to the magistrate who issues the writ proof by afficavit of the propriety of the process and the sufficiency of his testimony to sustain it. 
This would introduce the affdavit system into Connecticut, which has been wisely avoided and which has made New York practice open to so sharp criticism. Perhaps it is a necessity in so large a city as Greater New York. Nor would it be difficult for the lawyer who inspires the proceeding to get affdavits from parties, whom it would be difficult to find in a later prosecution for perjury, but whose written statements; in the absence of complicity, would be a justification of his issuing the writ.

Second. Require the Plaintiff in all suits which command an attachment of the body to procure the approval of their service, by written endorsement upon the process of a Judge of the Superior Court or other court of general jurisdiction. This plan would be safer than the affidavit plan.

Third. Abolish all attachments of the body upon civil process. While this method would in a few instances deprive suitors of a privilege which has heretofore been serviceable, we believe that these cases are so few and so infrequently necessary or even profitable, that on the whole they would better give way for the general good.

Attachment of the body in civil process has no justification as a method of satisfying a fair claim, either in contract or tort. To shut up a man in prison doesn't in any degree or to any extent pay the debt or damage. In this regard it satisfies only a sense of vengeance, which should have no place in the philosophy of Christian jurisprudence or Christian civilization. On the other hand the gratification of this passion is harmful to the community, including the plairtiff. Punishment for frauds is better confined to such offenses as are so harmful to the public as to be the subject of criminal law. The only real justification of the procedure is that men who have property sometimes prefer to produce it to satisfy their obligations, rather than to go to jail. This argument carried to its logical extreme would include debtors as well as tort feasors. But there is in theory an essential difference between debts and torts. The moral distinctions, however, often disappear in practice. A man who innocently converts a piece of personal property to his own use, and is unable to answer a judgment for its value, is guilty of a tort, but he may be much less worthy of incarceration for failing to satisfy the judgment than his neighbor, who laughs at an execution issued to collect his note which he could easily enough pay.

What with our abundant means of compelling disclosures in 
civil actions and in courts of bankruptcy and insolvency, and, if they are not broad and comprehensive enough, they can be enlarged, it would seem as if the practice of holding the body of a man, woman or child, for a. breach of duty to a plaintiff is a relic of earlier days, when cruelty and vengeance were deemed to be commendable elements in the philosophy of jurisprudence. Can we not trace it farther back, even to the uncivilization which allowed creditors of all kinds to reduce debtors to slavery, and which gave to the creditor a dominion over the body of his offending debtor?

We believe that such a step as the abolition of attachments of the body upon civil process taken by our Legislature would be in the way of progress, and as a certain result and one in which the community is deeply interested, would help to keep a noble profession pure from the presence of a small gang of petty extortioners and pirates, who now use the honored name of lawyer to prosecute a business which should only sail under a black flag.

Hartford, March 4 th.

Henry C. Robinson. 